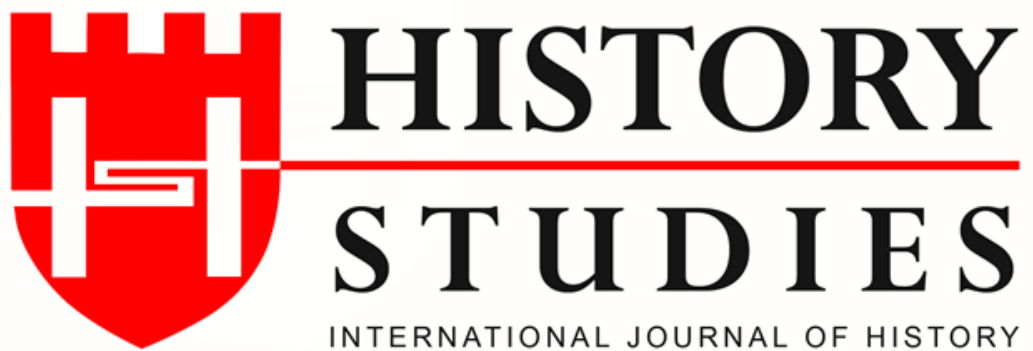

ISSN: 13094173 / (Online) 1309 - 4688 (Print)

Volume: 13, Issue: 2, April 2021

www.historystudies.net

\title{
NARRATIVE PRODUCTION PROCESSES IN THE STRUCTURAL CONSTRUCTION OF ANCIENT GREECE
}

Eski Yunanın Yapısal İnşasında Naratif Üretim Süreçleri

\author{
Assoc. Prof. Dr. R. Eser Kortanoğlu \\ Anadolu University \\ eserkortanoglu@gmail.com \\ ORCID ID: 0000000279839498
}

\footnotetext{
Makale Türü-Article Type : Araştırma Makalesi-Research Article

Geliş Tarihi-Received Date : $\quad$ 21.12.2020

Kabul Tarihi-Accepted Date : 15.03 .2021

DOI Number : 10.9737/hist.2021.1005
}
Atıf-Citation: $\quad$ R. Eser Kortanoğlu, "Narrative Production Processes in The Structural Construction of Ancient Greece", History Studies, 13/2, April 2021, p. 627-642.



HISTORY STUDIES

Uluslararası Tarih Araştırmaları Dergisi International Journal of History 13/2, Nisan - April 2021

627-642

Araştırma Makalesi

\title{
NARRATIVE PRODUCTION PROCESSES IN THE STRUCTURAL CONSTRUCTION OF ANCIENT GREECE
}

\author{
Eski Yunanın Yapısal İnşasında Naratif Üretim Süreçleri
}

\author{
Assoc. Prof. Dr. R. Eser KORTANOĞLU
}

\begin{abstract}
Öz
Eski Yunan'ın kültür kronolojisi Geometrik Dönem ile başlar. Bununla birlikte Geometrik Dönem'in büyük bir kısmı MÖ 12. Yüzyıldan itibaren başlayan Karanlık Dönem'in içindedir. Karanlık Dönem'in "Eski Yunan"ın temel yapısı için nasıl bir üretici süreç olduğu MÖ 8. yüzyıldan itibaren gözlemlenebilir ve değerlendirilebilir olmuştur. MÖ 8-7. yüzyıllarda yazıya dökülebilmiş söylemsel üretimin egemen öğesinin mythoslar olduğu ortadadır (Homeros ve Hesiodos). Mythoslar karanlığın içinde başka bir üretimdir ve kültürel kronolojinin bu parametrik boyutu "Naratif Dönem" olarak adlandırılabilir düşüncesindeyim. Naratif Dönem matriste başka bir boyut ve alan oluşturmuş öyküsel, söylemsel ve aktarımsal bir üretim aralığıdır. Böyle bir kültürel dönemin arkeolojisi de söylem ve göstergeleri odaklı bir arkeoloji olmak durumundadır. Naratif Dönem' in arkeolojisi söylem arkeolojisidir. Söylem bir yapıtaş1 olarak bizzat mythosun kendisidir. Bu duruma en önemli örneklerden biri makalede sökümü denenmiş olan Kalydon Yaban Domuzu Av1 mythosudur.
\end{abstract}

Anahtar Kelimeler: Naratif Dönem, Mythos, Söylem, Din, Kalydon Yaban Domuzu Av1, Yapısalcılik
The cultural chronology of Ancient Greece begins with the Geometric Period. However, most of the Geometric Period is in the Dark Period that started from the 12th century BC. How the Dark Period was a productive process for the basic structure of "Ancient Greece" has been observable and evaluated since the 8th century BC. 8-7 Centuries BC It is clear that the dominant element of discursive production, which could be written down in the centuries, is mythos (Homeros and Hesiodos). Mythos are another production in darkness and I think this parametric dimension of cultural chronology can be called "Narrative Period". The Narrative Period is a narrative, discursive and transferential production range that creates another dimension and space in the matrix. The archaeology of such a cultural period has to be an archaeology focused on discourse and indicators. The archaeology of the Narrative Period is discourse archaeology. Discourse is the mythos itself as a building block. One of the most important examples of this situation is the Calydon Wild Boar Hunt mythos, which was deconstructed in the article.

Keywords: Narrative Period, Mythos, Discourse, Religion, Kalydon Boar Hunting, Structuralism 


\section{Introduction}

It is necessary to focus on a specific geographical area in order to examine the religious systems of the Ancient Period (refers to the Bronze Age and afterwards within the context of this paper). This geographical area which is the core for cultural production consists of Aegean and Eastern Mediterranean, Continental Greece, Anatolia, Mesopotamia, Levant and Egypt (refers to Eastern Mediterranean as required by a holistic approach hereinafter in the paper). A pluralist insight and worship was in question in religious terms in the Bronze Age and later in Eastern Mediterranean. ${ }^{1}$ The humankind created in his mind the "transcendent" gods in human form (from time to time substantially human form) but thought to have much more physical and divine powers than him. Those mental designs in question transformed into systematic regular structures within centuries and millennia. This systematic regular structure has been named as religion. Religion, religious institutions, priests and the entire religious activity personnel, religious architecture and ornaments (figurative and decoration) have been very significant elements of socio-cultural history (at the same time history of realpolitik, ideology and political economy). The most significant question in this regard is as follows: Why did the humankind transformed its god insight which is his own design (mental construction processes) and which has the similar form with the humankind ${ }^{2}$ (anthropomorphic), namely its own reflection into gods? In other words, why did the humankind put himself into celestial (masculine) power? It is because religion and religious systems have been one of the most dominant power structures in terms of social culture, social hierarchy and state organizations since they gained a specific structure (an ordinate social structure and a transcendent power). ${ }^{3}$ Furthermore those structures are the prevailing and permanent ones on the bases of human inner world, world perception reflexes and belief/worship. Those sharp dogmatic characters of religious elements arise from the fact that such elements are a transcendent thought. Humankind managed to perform a transcendent divine design in his selfdirected innate mind structure. The collective cognitive communication empowered this design and transformed it into a big systematic set (with too many subsets) and produced their rituals and worship models. ${ }^{4}$ This cognitive competence of humankind is a feature which has even shaped the present day. Ruling models, socialization and production models have continuously changed and developed but both religious thought and systematic ruling have always remained the same and consolidated themselves continuously due to its nutrition cycle.

Ability of the humankind to imagine the transcendent reflection of its original character (physiognomy, power and character) as a god is the ideological manifestation of creating himself in his unconsciousness and repeating the creation continuously. One may think of this innate reflex as a two directional revelation. The process of creation of a transcendent figure(s) where the humankind will abstain from his own reflection comes in sight as a construction of unconsciousness whereas the humankind both classified fear and could overcome with the instinctive fear classified thanks to those figures.

\footnotetext{
${ }^{1}$ Robert Neelly Bellah, Insan Evriminde Din, Eski Taş Çă̆ından Eksen Çă̆ına, Çev: Mete Tunçay, İstanbul Bilgi Üniversitesi Yayınları, İstanbul 2017, s. 266-287, 382-399.

${ }^{2}$ Walter Burkert, Greek Religion, Harvard University Press, Massachusetts 2003, s.182-189.

${ }^{3}$ Bellah, age, s. 266-287.

${ }^{4}$ Sigmund Freud, Dinin Kökenleri, Çev: Ayşen Tekşen, Pavel Yayınevi, İstanbul 2012, s. 51-148; Alan Barnard, Simgesel Düşüncenin Doğuşu, Çev: Mehmet Doğan, Boğaziçi Üniversitesi Yayınları, İstanbul 2016, s. 71-92.
} 
The humankind is afraid of the position he had in the wild nature where he naturally lived in the prehistoric era. Many phenomena the reason of which he does not know realize in the nature. The humankind tries to survive in the wild nature and is afraid of himself in other communities, as a part of the wild nature. The humankind is both afraid of himself (his reflection) and gains an apparent feeling of confidence (shelter/house, sacred area /sacred structure, city wall/fortress are the "visible ones" in Foucault' terms, as the concrete indicators of this feeling of confidence) against his radical (as suggested by Lévi-Strauss, there is nothing radical but there are variations) ${ }^{5}$ fears when he transforms its own reflection into its god. Freud regards this act as the manifestation of unconscious desire (production of location) and shows it with the metaphor of "being at home". ${ }^{6}$ The fears of the humankind against the gods which are his own reflection (self-modeling of the humankind when it is necessary to make a description of god is an extremely important egocentric to be dwelled on many times but this position has been attained gradually since the period of totems $)^{7}$ and creation is settled in a specific mental structural plane. When fear is settled in human psychology anti-fear actions (and life practices) are created and these become classifiable in time and this is what we call culture. The idea of god provided a stage of transition from the fear of nature (wildlife full of natural phenomena and practice of survival) toward culture. The idea of god has become an element of transition itself in the polytheistic system. However it is a permanent element of transition which could not be renounced, which was not desired to be renounced since it connected human both with human and with the past. It is further an element of transition which could not be renounced since "its completion is postponed", in Derrida's terms. ${ }^{8}$ The God is a continuity which provides transition. In this regard the God is connected with the thought of infinity and the idea of infinity is a significant hierarchical position element which reinforces the idea of god (single god) and which is even combined with it (integration is always together with transformation). ${ }^{9}$ The god is an element of transition in human form, transcendent and eternal. The thought of god positioned in the hierarchy in this manner has not been the one only waiting in the abstract extension where it is positioned and assumed a productive attitude. It has been one of the most significant trivets in shaping a production society and in attaining a systematic order, the cosmos, together with political economy and ideology based realpolitik processes.

Human mental structure has not allowed fictionalizing any being with the image of which is other than/different from him (unconscious anthropomorphic reflex) as god (transcendent phenomenon). Namely, the humankind has stipulated from the beginning in its unconsciousness that the divine figure which would rule him should look like himself (the process of formation anthropomorphic stage). The humankind has modeled "himself as he wanted to be" which is his own creature, rather than himself as the god. This model first evolved to the rule of priest-kings and then feudalism/kingdom/empire rule, and has collaborated and communicated

\footnotetext{
${ }^{5}$ Claude Lévi-Strauss, Uzaktan Yakından, Çev: Haldun Bayr1, Metis Yayınları, İstanbul 2018, s. 183.

${ }^{6}$ Jacques Lacan, Psikanalizin Dört Temel Kavramı, Çev: Nilüfer Erdem, Metis Yayınları, İstanbul 2017, s. 50.

${ }^{7}$ Claude Lévi-Strauss, Yaban Düşünce, Çev: T. Özgüç, Yap1 Kredi Yayınları, İstanbul 2000, s. 61-99; Freud, age, s. 51-68.

${ }^{8}$ R. Eser Kortanoğlu, Varlık ve Tapınak; Eski Yunan Tapınağının Kavramsal İnşası Üzerine Arkitektonik Bir Deneme, Bilgin Kültür Sanat, Ankara, 2018a, 1-56 (also see Bibliography).

${ }^{9}$ Carl Gustav Jung, Dört Arketip, Çev: Zehra Aksu Yılmazer, Metis Yayınları, İstanbul 2015, s.14.
} 
uninterruptedly with the ruling power all the time in the period of monotheist religions. ${ }^{10}$ One is the power of worldly life and strength willpower, a power built on conformism and the other has established its systems and institutions (administrative and architectural) on the power of the afterlife. However one should keep in mind that "power" and "strength" and "strength willpower" are different things and those "differences" can be defined as hierarchical layers in semantic structures both visible and invisible.

The element through which we learn all this process, try to understand and assess in antiquity is mythology (visual and discursive set of structural and religious indicators). Because, in LéviStrauss' terms, the events that happen on a specific moment of time create a continuous structure. This structure is related to all times. ${ }^{11}$ The mythological elements which we see, reveal and define on plastic, architectural plastic, vase picture, frescos, mosaic grounds, coins, all sorts of small findings are the elements through which we can understand the design mechanics of the era, construction and distribution fiction of the structure. We cannot find any pre-Classical period (we can also say Pindaros partially in this set) written out discourse production (in Foucault's terms, elite episteme) except for Homeros (and Homeric hyms) and Hesiodos. Mythoses (which is, could be and have been cyclical too depending on various features particularly including configuration and distribution) are fabular/successive/narrative narrations the "explanation" character of which is prominent. Those heroical and sometimes epic stylistic narrations have some reason. They transfer within the scope of their fictional but diachronic architectures, within the framework of cause and effect relation a condition of formation which happened in the past (transferred to us in its completed form) and which enlighten those old times lived (providing communication, being translated). ${ }^{12}$ Indeed, they pose a primitive (and divine) pre-stage (a fantastic but basic pre-stage) to historicity and history writing (ideological and socio-cultural). That is to say, no antic author could manage to rescue themselves from mythical narrations or metaphors until Late Antiquity. For this reason, they are defined with the adjective of "basic". It is necessary to narrate and transfer what the structure is and what it is made of for configuration of the structure. It is not possible to transit from mythos to logos in any other way (particularly in the plane of Platonic perception and transfer). ${ }^{13}$ We confront duality within singularity of worship and state of belonging for the first time in Ancient Greek religious architecture. In fact this is an answer given to Plato in the context of philosophy of architecture before Plato was born.

Mythoses are naturally semantic structures. One should focus on the structure under a specific mythos rather than its symbolic meaning or text content in order to discover its meaning. This structure inalterably reveals the tensions in social relations and economic problems. ${ }^{14}$ The social relations and economic-political tensions shall be discussed in the following sections. However I think that it is possible to make an "addition" to this expression: At the same time this structure

\footnotetext{
${ }^{10}$ Pierre Bourdieu, Akademik Aklın Eleştirisi Pascalca Düşünme Çabaları, Çev: Burcu Yalım, Metis Yayınları, İstanbul 2016, s. 205-213.

${ }^{11}$ Claude Lévi-Strauss, Yapısal Antropoloji, Çev: Adnan Kahiloğulları, İmge Yayınları, Ankara 2012, s. 300.

${ }^{12}$ Mihail Mihayloviç Bahtin, Söylem Türleri ve Başka Yazılar, Çev: Okan N. Çiftçi, Metis Yayınları, İstanbul 2016, s.65.

${ }^{13}$ R. Eser Kortanoğlu, Varlık ve Tapınak; eski yunan tapınağının kavramsal inşası üzerine arkitektonik bir deneme, Bilgin Kültür Sanat, Ankara, 2018a, 97-134 (also see Bibliography).

${ }^{14}$ Donna Rosenberg, Dünya Mitolojisi- Büyük Destan ve Söylenceler Antolojisi, Çev: Koray Akten - Erdal Cengiz, İmge Yayınları, Ankara 1998, s. 22; Zühre İndirkaş, Antik Yunan'da Mithosun Serüveni, Tekne Yayınları, İstanbul 2017, s.51.
} 
inalterably reveals the signs, relations and tensions between consciousness and unconsciousness of humankind. This sentence refers for me to a continuous-cyclical desire set that appears as the desire of existence, desire for desire in the process of existence and desire for being desired. ${ }^{15}$ And the element which makes this phenomenon continuous is "fear". The relation between fear and desire manifests itself as virtue, lack of virtue and punishment in the systematic religious structures. What can or cannot be made ground in this manner in discourse and tradition. Interpretation of culture production of humankind looking at produced culture production is the only way of interpretation.

Configuration mythoses are the paradigmatic construction materials which played significant role in the construction of Ancient Greece. Those materials should be considered as regular blocks (discourse). The basis for construction begins with transformation narrations for Ancient Greece. It has been necessary for economic-political fictions to shift to an existence plane in the light of periodical historical and cultural relations, in the configuration of chief god Zeus and Zeus/Greek religion until the religious power of the basic gods and Zeus and his entourage is established particularly in the Late Neolithic, Bronze Age and Dark Age in Eastern Mediterranean and Aegean. ${ }^{16}$ Transformation is a restoration (making what it should be) and for this reason we can expect it to have conservative elements (here we should understand the thing which should be particularly as the entire unwritten rules). The masculine divine forms the seeds of which were spread in the Late Bronze Age should be recognized and settled in the broad geographical area of the mother goddess. These seeds spread in the Late Hellas namely Mycenean Period settled in the social consciousness and created a primitive system in a period which was called Dark Period as well and which I personally find quite productive (it is largely eastern supported and has produced the holistic structure called "Ancient Greece"). The process of its becoming power configurations which I call Classical Paradigm is completed in the Archaic Period (even, no later than the Early Archaic Period). ${ }^{17}$ In other words, discourse (mythos) production came to an end in the Archaic Period. The mythoses related to the creation of the world, gods and order, power struggles of gods (power struggles came to an end when order was established in the cosmos and the power of third generation gods realized), all "makhias", Herakles and his Works, Argonauts Expedition, Calydon Wild Boar Hunting, Trojan War, the struggles and competitions performed to be the chief divine figure of a region, narrations related to certain heroes particularly including Theseus, Pelops, Oedipus are the most significant, most popular, most needed ones of those building blocks. Their repetitions were found to be important and they were highly presented in or on texts, fictions, structures and elements. Some were described in the form of parts in a whole as it is the case for example in François vase. In this context, definition of the vase in popular culture as "Visual Bible" metaphorically does not seem to be wrong. As it is well known, the vase is an

\footnotetext{
${ }^{15}$ Jacques Lacan, Baba'nın Adları, Çev: Murat Erşen, Monokl Yayınları, İstanbul 2014, s. 48, 61-64, 78-79; see also J. Kristeva literature.

${ }^{16}$ R. Eser Kortanoğlu, Varlık ve Tapınak: Eski Yunan Tapınağının Kavramsal İnşası Üzerine Arkitektonik Bir Deneme, Bilgin Kültür Sanat Yayınları, Ankara 2018a, s. 141-147; Cansın Okan, Mitoslar ve Tasvirler Işı̆ğında Antik Ege Coğrafyasında Dişi Tanrısal Figürler: Kök, Karışım ve Değişim, ( Anadolu Üniversitesi, Sosyal Bilimler Enstitüsü, Yayımlanmamış Yüksek Lisans Tezi), Eskişehir 2019, s. 56-68, 110-168.

${ }^{17}$ Kortanoğlu, age.
} 
Attic black figure crater dated approximately to 570 B.C. ${ }^{18}$ The abovementioned mythoses or the roles assumed by the figures within the system were described in the pictures on the vase. Those descriptions reflect Homeros, Hesiodos and other configuration discourses in the form of visual descriptions.

The culture chronology of Ancient Greece starts with the Geometric Period. Nevertheless a large section of the Geometric Period is within the Dark Period which starts from $12^{\text {th }}$ century B.C. It had been observable and assessable from $8^{\text {th }}$ century B.C. what kind of a productive process the Dark Period was for the ground structure of "Ancient Greece". ${ }^{19}$ It is apparent that the dominant element of discursive production that could be written out in $8^{\text {th }}$ and $7^{\text {th }}$ centuries B.C. is the mythoses (Homeros and Hesiodos). Mythoses are another type of production in the dark and I consider that this parametric dimension of cultural chronology could be named as "Narrative Period". The Narrative Period is a fabular, discursive and citational production interval which created another dimension and area in the matrix. The archeology of such a cultural period is to be an archeology with discourse and indicators focus. The archeology of the Narrative Period is archeology of discourse. Since there was no writing or it has not been detected yet in Aegean geography in the Dark Period (lack of finding and lack of writing in Ancient Greece is considered equal), they are fabular form mythoses which we name discourse. Discourse is mythos itself as a building block. However mythos has several forms:

1- Mythos which is mythos. It is the purest form of mythos (the first form that we could detect) itself. It is the form of mythos which Jung calls "First Sample". It is the first narration (arbitrary grading) (what makes it the first narration is the process of being discovered). ${ }^{20}$ Though it is very difficult to trace it radically, it could be possible to detect certain regional and chronological details and relations.

2- Mythos which is being transferred. Mythos is at the same time an interactive praxis of cultural formation (production). It is the version of the sample in another region or cultural geography. It is a significant and necessary stage to detect the direction of cultural interaction and cultural differences. Detection of formation of the same focus through non-interactive production is separate significant archeological and epigraphic/literal information.

3- Mythos which changes while being transferred. The element which first changes is at the same time which degenerates first. Degeneration shows us the Power and Resistance Focuses as well, at the same time. Does this degeneration have a standard transformation mechanic? Is change being constructed with local parameters (such as use of local quarry rather than Paros marble)? This stage is a significant cultural parameter to detect the answers of those questions.

4- Mythos which changes after being transferred. The mythos that changed after being transferred offers significant assessment and comparison parameters on the mental structure of

\footnotetext{
${ }^{18}$ Thomas H. Carpenter, Antik Yunan'da Sanat ve Mitoloji, Çev: Bensen B.M. Ünlüoğlu, Homer Kitapevi, İstanbul 2002, s.192-193, fig. 248; John Boardman, Siyah Figürlü Atina Vazolarl, Çev: Gürkan Ergin, Homer Kitapevi, İstanbul 2003, s.31, 33-34, 229, fig. 46.1, 46.3; Jenny March, Klasik Mitler, Çev: Semih Lim, İletişim, İstanbul 2018, s. 186.

${ }^{19}$ Kortanoğlu, age, s. 97-123.

${ }^{20}$ Lévi-Strauss, age, s. 300.
} 
the cultural topography where it changed, the design mechanic of this structure, socio-cultural traditions and conditions. ${ }^{21}$

5- Mythos transformed into writing. It is the sum of Literal resources (Homeros and later), Philosophical resources (Ionia philosophers and later), Historical resources (Herodotus and later) and the holistic set and viewpoint covering all. From this point, it is possible to compare and match the written texts and archeological findings, consequently to make sharper scientific assessments. Furthermore this stage is a position (a Derrida style trace " $X$ ") where it is possible to put a trace on the conceptual foundations of transition from mythos to logos. ${ }^{22}$ From this moment on, it becomes possible to demount the systematic structure called Ancient Greece. ${ }^{23}$

6- Mythos various variations of which were formed in the written period. The Late Hellenistic and Early Roman Empire periods and later periods are the periods of creation of mimesis classical mythos by the authors (such as Vergilius and Ovidius), particularly the authors of Empire Period who seriously transformed the Greek literal works through infinite diversifications and emotional top comments. Now a literature plane and narration is in question. In other words, it is the Early Metaphors Age. We experience the late times of this period today.

As regards to Ancient Greece, although Neolithic and Bronze Age Mother Goddess of Eastern Mediterranean has similarities under different names from time to time, they have been parts of different projections. This big paradigm refraction in the religious system, which is one of the most important elements of the structure, has created a big tension both in the society and in interregional relations (both in the state instrument and in the power insight). Artemis, as a Mother Goddess projection in the Continent or as one of the versions of a Mother Goddess transformed with another definition (as a minor indicator of a translated a Mother Goddess) is the power and more importantly structure indicator of an agriculture society (partially together with Demeter) in the Configuration Age (Narrative Period) ${ }^{24}$ Because, the thing which provides survival of the society is basically fertility and agricultural production of the soil. ${ }^{25}$ The discourse of this indicator (what can be said) has been created with Calydon Wild Boar Hunting mythos in Continental Greece, Aitolia Region, Calydon (First example: Homeros/lliad). Calydon Artemis temple and each monumental mass having the plastic description of the mythos is indeed the visible one of this system (such as Tegea Athena Alea temple eastern pediment sculptor program or Gölbaş1Trysa Heroon relief). ${ }^{26}$ As regards to subject, the purpose is giving the moral to an agricultural

\footnotetext{
${ }^{21}$ Different variations fact, see Lévi- Strauss, age, s. 183.

22 Kortanoğlu, age, s. 97-134; R. Eser Kortanoğlu, "Logocentric Structures, Platon and Dual Worshipping Phenomenon", VI. Ylldız Teknik Üniversitesi Sosyal Bilimler Kongresi, Tam Metin Bildiri Kitabı, İstanbul 2019, s. 281290.

${ }^{23}$ R. Eser Kortanoğlu - Müge Savrum - Kortanoğlu, “ Kıta Yunanistan Mimarisinde Birden Fazla Girişi ve Mekanı Olan Anıtsal Yapılar: Tarihöncesi ve Tarihsel Uzamlar Kütleler ve Çevirileri”, Cedrus VIII, 2020, s. 121.

${ }^{24}$ Burkert, age, s. 149-152; Mircea Eliade, Mitler, Rüyalar ve Gizemler, Çev: Cem Soydemir, Doğubatı Yayınları, İstanbul 2017, s.209-210.

${ }^{25}$ Age, s. 157

${ }^{26}$ Signe Borfoed, "The Cults of Kalydon, Reassessing the Miniaturised Votive Objects", Proocedings of the Danish Institute at Athens, Vol. VIII, Edt. K. Winther-Jacobsen, R. Frederiksen, S. Handberg, Atina 2017, s.131148; Signe Barfoed, "Rediscovering Artemis Laphria at Kalydon", Proocedings of the Danish Institute at Athens, Vol. IX, Edt. K. Winther-Jacobsen, N. von Eggers Marieggard, Atina 2019, s.189-196; Charles Dugas - Jules Berchmans Mogens Clemmensen, Le Sanctuaire d'Aléa a Tégée au IVe siécle, Paris 1924, s.79-83; Erika Simon, Meleager und Atalante Abegg-Stiftung, Bern 1970, s. 19; A. F. Stewart, Skopas of Paros, New Jersey 1977, lev. 53; A. F. Stewart, Skopas in Malibu, California 1982: back inner cover restitution trial.
} 
society over a discourse (while transferring the non-written rules of the paradigm) and configuration of a structure that defines and even arranges past, present and future, by the Classical Paradigm within the Narrative Period. ${ }^{27}$ This configuration has been translated over heroism and love so far. However the mythos has signs which reveal deeper unconscious structures. The discourse contains quite conservative clues. Artemis Is the only divine figure to whom no sacrifice is offered. It is not possible in an agricultural production society to forget the persona closest to its mother goddess (even in François vase, Artemis is described as potnia theron together with wilds animals) during the agriculture festivals. However the mythos begins with this oblivion and divine wrath as punishment. The main tension here is that there is no longer a mother goddess to whom an offer is to be made in an agricultural society (absence of fertility goddess remunerates the Big Mother persona as of Neolithic period, for Mother Archetype). ${ }^{28}$ Since there is no mother goddess this offer was not / could not be made.

Calydon wild boar hunting mythos is one of the most important discourses of configuration for Ancient Greece and consequently was frequently described. ${ }^{29}$ According to the mythos, Oineus, the king of Calydon in Aitolia Region in Continental Greece offers sacrifice and expresses his thanks to the gods and goddesses as a tradition following the harvest. He forgets to offer sacrifice to Artemis, the goddess. Artemis who resent this situation sends an extremely big wild boar that destroys all agricultural fields in the country. Meleagros, Oineus' son brings together many famous hunters and heroes from neighbor counties to hunt the wild boar (it is also mentioned in the narrations that Meleagros is the son of Ares, the god born from his relationship with Althaia). ${ }^{30}$ Atalante is also one of the hunters invited. ${ }^{31}$ Homeros (Il.IX, 529-599), Kallimakhos (h.III,215 etc.), Apollodoros (I,8,2), Diodoros Siculus (IV,34,3-6), Pausanias (VIII, $45,2-6-46,1-5-47,2$ ) and Ovidius (met.VIII, 284-9, 316 etc.) narrate the participants of this hunt and the events (with apparent differences from time to time). ${ }^{32}$

Pausanias mentions in the text where he narrates the wild boar hunting, Tegea Athena Alea temple designed and sculptured by Skopas, located in Arcadia Region (VIII.41.8-VIII.45.54). He gives a list of those participating in the hunting while he narrates the scene of Calydon wild boar hunting, decorating the Eastern (Main) façade pediment. He writes that Atalante, Meleagros, Theseus, Telamon, Peleus, Polydeukes, Iolaos, Prothoos and Kometes who are Thestius' sons, Epokhos, Ankaios, Kastor and Amphiaraos, Hippothoos' son Kerkyon, Agamedes' son, Stymphalos' son and Peirithoos are ordered in the scene, in two sides of the wild boar. ${ }^{33}$

All those famous hunters and heroes make feast in Oineus' palace for nine days. They depart for hunting on the tenth day. Presence of a woman within the group is not tolerated (beyond sexist

\footnotetext{
${ }^{27}$ for Classical Paradigm, see Kortanoğlu, age, 2018a.

${ }^{28}$ Jung, age, s.17-24

${ }^{29}$ R. Eser Kortanoğlu, "Une femme sportive dans les mythes grecs antiques” Colloquium Anatolicum X, 2011, s.167.

${ }^{30}$ Pierre Ellinger, “Artemis, Antik Dünya ve Geleneksel Toplumlarda Dinler ve Mitolojiler Sözlüğü” Ed. Yves

Bonnefoy, Dost Kitabevi, Ankara 2000, s. 65-69; Susan Woodford, "Meleagros", LIMC VI,1992.

${ }^{31}$ E. Saglio, "Atalante", Daremberg-Saglio I, 1877; Boardman, age, 1984.

32 Carpenter, age, s.192-193, fig. 284; March, age, s.184-187; Karl Kerényi, Yunan Mitolojisi; Tanrllar, Insanlar ve Kahramanlar, Çev: Oğuz Özügül, Say Yayınları, İstanbul 2019, s. 398-405; Robert Graves, Yunan Mitleri C. I, Çev: Uğur Akpur, Kolektif, İstanbul 2020, s. 321-326.

${ }^{33}$ Stewart age, 1977, s. 51, lev.53; Stewart age 1982: back inner cover restitution; A.F. Stewart, Greek Sculpture, Yale University Press, New Haven 1990, s. 182-185; John Boardman, Yunan Heykeli. Geç Klasik Dönem, Çev: Müjde Peker, Homer Kitabevi, İstanbul 2014, s. 25, 56-57, 191-192, fig. 222.7.
} 
attitudes, maybe because Atalante is maiden or because of her qualifications that could be named as equivalent of Artemis in certain mythoses?). However Meleagros manages to calm down the other members of the group. The reason for this is that he probably fell in love with the young girl and wants to have a baby born by Atalante despite his marriage with Kleopatra. The hunting is quite difficult. Some of the heroes die (Ankaios, Eurytion). It is Atalante who injures the wild boar for the first time with the array she shot. Thus she reinforces her fame. In the end Meleagros kills the animal with a knife he sticks into its breast. This situation entitles Meleagros to get the head and fur of the wild boar. Meleagros wants to give his prize to Atalante immediately. This desire leads to a big dispute among the ones who participated in the hunting. His uncle Thestios and his sons (and other uncles) object to Meleagros. They think that if Meleagros does not want to get the hunting spoils, he should give them to his closest relatives among the hunters, namely to them. Meleagros who is very angry with this request kills Thestios' sons Prothoos and Kometes. Then he gives the head and fur of the wild boar to Atalante as gift. Meleagros' mother Althaia who learns what happened is furious with her son too, since he killed her brothers and does something which will give an end to her son's life under the influence of this rage. She throws the partially burnt firewood that she kept since his babyhood. When Meleagros is a seven-day old baby (or on the date he was born) the fate goddesses show Althaia (whose name is coined from the verb of "to heal") a firewood in the kiln and say that when that firewood burns to ground Meleagros will die (The first one, Moira Klotho says that Meleagros will be a charitable person, the second one, Moira Lakhesis says that he will be a hero. The third one, Moira Atropos talks about the burning piece of firewood). Althaia immediately extinguishes the kiln and hides the partially burnt firewood in a chest. But when Meleagros kills his uncles, his mother gets furious and throws the firewood she hid in the fire. When the firewood burns out, Meleagros dies. Althaia who subsequently realizes what she has done commits suicide. Meleagros' wife Kleopatra commits suicide too. Atalante mourns after Meleagros' death. ${ }^{34}$

What does this mythos teach us? A trial of analysis of Calydon Wild Boar Hunting mythos within the framework of Lévi-Strauss' structuralist Oedipus mode ${ }^{35}$ depending on its own innate sets is given as follows. Accordingly, the following model arises;

\footnotetext{
${ }^{34}$ Edith Hamilton, Mitologya, Çev: Ülkü Tamer, Yap1 Kredi Yayınları, İstanbul 2018, s. 130-134; Kerényi, age, s. 398405; Pierre Grimal, Dictionnaire de la Mythologie grecque et romaine, Paris1969, s. 284-286; Azra Erhat, Mitoloji Sözlüğ̈̈, Remzi Kitabevi, İstanbul 1996, s. 202-203; Graves, age, s. 321-326; Ellinger, age, s. 65-69; A. Schnapp, “Av. Eski Yunan'da Av kahramanları ve Mitleri”, Antik Dünya ve Geleneksel Toplumlarda Dinler ve Mitolojiler Sözlüğ̈̈, Ed.Yves Bonnefoy, Dost Kitabevi, Ankara 2000, s. 90-92; Carpenter, age, s.192-193, lev. 284; R. Eser Kortanoğlu, Atalante; İkonografik Bir İnceleme. (İstanbul Üniversitesi, Sosyal Bilimler Enstitüsü Yayımlanmamış Yüksek Lisans Tezi ) İstanbul 1999, s. 6-24, lev. 1-37; Kortanoğlu, age, 2002, s. 428-429; R. Eser Kortanoğlu "Yas (Mourning)", A. Vedat Çelgin'in 68. Doğumgünü Onuruna Makaleler, İstanbul 2018b, s. 529-534; March, age, s. 184-187.

${ }^{35}$ Lévi-Strauss, age, s. 307-310.
} 
1a

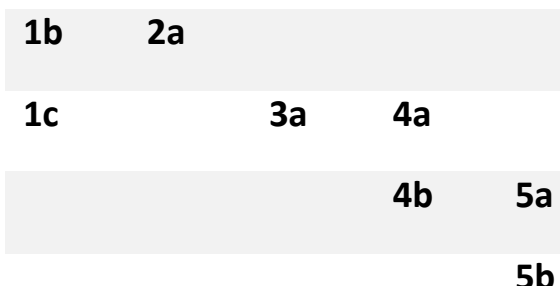

2b

$6 a$

$5 c$

2c

6b

$3 b$

$6 \mathrm{c}-\mathrm{d}$

1a: Oineus, Calydon (Artemis worship) king in Continental Greece Aitolia Religion offers sacrifice to the gods and goddesses following the harvest.

1b: Oineus does not offer sacrifice to Artemis (or forgets to make).

1c: Oineus invites heroes for hunting.

Oineus' religious and social praxes.

2a: Artemis is furious with Oineus. She sends a wild boar that destroys all agricultural fields.

$2 \mathrm{~b}$ : The relatives participating in the hunting furious with Meleagros. The demand the head and fur of the boar.

2c: Meleagros' mother Althaia is furious with her son. She throws the partially burnt out firewood in the fire.

Action, the divine anger caused and its results.

3a: Meleagros falls in love with Atalante (secret affair).

3b: Atalante mourns.

Emotional reflexes of love.

4a: Atalante from Arcadia Region Tegea (Athena worship) is the one who injures the boar with arrow.

4b: Meleagros kills the wild boar with spear/knife.

Hunting process.

5a: Meleagrosis entitled to get the head and fur of the boar since he kills the boar.

5b: Meleagros wants to give the head and fur of the boar to Atalante.

5c: Meleagros gives the head and fur of the boar to Atalante as gift. 
Issues related to the prize of hunting. Appearance of conservative structures.

6a: Meleagros kills his relatives who participate in the hunting and get furious with him.

6b: Meleagros dies.

6c: Althaia commits suicide.

6d: Cleopatra, Meleagros' legal spouse commits suicide.

Death (kill, die, commit suicide).

\section{Relations between parameters and communication network;}

1a: Beginning. Submission of thanks to the gods, clear presentation of characters of the love offered and identity of the offering person social (and ideological) hierarchy, in other words social classes; Gods, king (and nobles) and subject.

$1 \mathrm{~b}-2 \mathrm{a}$ : Establishment of cause and effect relation in paradigmatic provisions. No offer is made to the goddess and the goddess makes judge in the end. Which goddess? The goddess concerned with fertility and wild nature. Which persona? Artemis, one of the female figures closes to the mother goddess (in continent context). Why is the offer forgotten? To strengthen the judgment and the structure. In the architecture of discourse, a crime/offense should arise firstly in order to be able to make a judgment. In this context, it is an offense not to make an offer. If there is offense, there is punishment, too. The punishment is not merely sending the boar and destroying the environment. The punishment is the last section containing fate and death themes of the mythos as dealt particularly in the tombs of Empire Period. ${ }^{36}$ This repetition continuity indicates clearness of the message (translation) (and how much this tragedy is liked).

$1 \mathrm{c}-3 \mathrm{a}-4 \mathrm{a}$ : Establishment of local and inter-regional relations network. People come together for hunting and the king of the period, aristocratic (noble class) and hero hierarchy is explained (Heroic Age). Social and emotional relations begin within the hunting community (among big families of the regions). The fiction of the future events begins to be created.

$4 \mathrm{~b}-5 \mathrm{a}$ : The wild boar is killed. This superior skill has a prize. The conflict between old traditions and innovation elements are transferred through prize (and love).

5b: Resistance focuses and Innovation willpower manifests itself through love. Structural refractions are turned to be discourse through love.

$2 b-6 a$ : Reactions of the tradition to resistance focuses. If there is deadlock somewhere, equation is created. If there is equation, there is equality. The manner of construction of equality manifests us the solution method as well. Solution methods turn to be law clauses by time. Solon's Period (Archaic Period) is waited for this in Ancient Greece.

5c: Transformation of resistance into reality.

$2 \mathrm{c}-6 \mathrm{~b}$ : Show of strength of Classical Paradigm. The mother's action which will lead to her son's death.

\footnotetext{
${ }^{36}$ Kortanoğlu, age, 1999; Kortanoğlu, age, 2002.
} 
$3 b-6 c-6 d$ : Result. Tragedy. Gaining resistance focuses by the traditional conservative structure first creating and then terminating: Creation of discourse and traditions through visible and invisible formation.

We confront Calydon hunting scenes more frequently on Attica vases of the sixth century B.C. with black figure, case paintings of the fourth century B.C. with red figure and tomb reliefs of the second-third century A.D. Furthermore, Calydon Wild Boar Hunting was described in Gölbaş1Trysa Heroon reliefs, one of the most important works of the fourth century B.C. and Tegea Athena Alea Temple eastern pediment. ${ }^{37}$

Settlement of identities of the gods, refraction and modification of traditions, religious and social relations network both within the society and between regions are discourses for the future in the stage of configuration. Those discourses reveal the unconscious bases of socio-cultural life as an indicator of the Heroic Age. Meleagros, a significant figure of the Heroic Age and Akhilleus, one of the most significant figures of Trojan War mythos have two important similarities (repeated form/model) (in Il. 9,528, Phoenix says "I remember a very ancient event" and reveals the time difference between the two epic periods. Heroic Age is a significant milestone in the configuration period but if there is a Heroic Age, there should also be a pre-Heroic Age and this is one of the significant departure points to question the hierarchy and time order between the mythological periods). Meleagros' mother Althaia gave her son immortality (at least for a while) by taking the partially burnt firewood and hiding it as required by the warning of fate goddesses. Akhilleus' mother Thetis held her son in the heels and made him dive into Styks River and provided him with partial immortality (if he does not have any problem with Achilles tendon) in this manner. Two mythological figures are interconnected through Calydon Wild Boar Hunting mythos, and the two mythoses communicate. Peleus (Akhilleus' father), another member of the Heroic Age participated in both the hunting and Argonauts Campaign, just like Meleagros. Another significant repetition is that the two enter in war struggle, are offended with the struggle and are persuaded (Kleopatra) or turn back with their own initiative as a result of a big psychotraumatic development (Patroklos' murder) and are victorious. The two took part in the same patterns of events, namely Meleagros in Calydon Wild Boar Hunting mythos, Calydon and Kourets/Kuretas (struggle between mother Althaia's family/clan ${ }^{38}$, and Akhilleus in Trojan War. Another significant element which connects the subject to Trojan War is Artemis herself. Artemis does not allow Akhaean fleet to depart because of wind. Agamemnon sacrifices her biological daughter Iphigeneia (or has to sacrifice her). Human sacrifice is not a standard religious behavior ritual of Ancient Greece society it is a reference made to the social memory of humankind, maybe to a very far past. The conservative structure deemed such a discourse necessary. Artemis, goddess of wild animals who is Zeus' daughter and Apollon's sister exhibited marginality far beyond its standard persona of the Continent, in Iphigeneia mythos. Analysis of the mythos is beyond the subject of the paper. Thus we have detected the repeated communication elements related to Calydon hunting.

\footnotetext{
${ }^{37}$ Dugas et al. age, 1924; K. Fittschen, Meleager Sarkophag, Frankfurt am Main, 1975; G. Koch, Die mythologischen Sarkophage 6; Meleager, Berlin 1975; G. Koch, Sarkophage der römischen Kaiserzait, Darmstadt 1993; Boardman, age, 2003; Boardman, age, 2005; Boardman, age, 2014; Carpenter, age, s. 192-193; Kortanoğlu, age, 1999, s. 6-27; Kortanoğlu, age, 2002, s. 425-447.

${ }^{38}$ March, age, s.184-187.
} 
The most significant production forms of human communities as of transition to permanent settlement beginning from the Neolithic Period have been agriculture, architecture and primitive industry (ceramic, mineral etc.) necessary to sustain daily life. On the other hand these parameters can vary in geographic, climatic, topographic terms and in terms of underground and over ground resources. Additionally culturing the plants and fertile agriculture has been a unique threshold for human life sustainability. As mentioned at the beginning of the paper, the second threshold is transformation of different types of systematic rituals into religion. Looking through the religious systems from a holistic point of view, we basically encounter a masculine celestial figure and a feminine terrestrial (earth, soil) figure. Both existence and continuity of the social order and feminine terrestrial figure which is the counterpart of soil, agriculture and agricultural fertility has transformed into Mother Goddess by time and leaves its mark on the Neolithic and Bronze ages in the Eastern Mediterranean. In 2000s B.C. Indo-European communities arrived at the Eastern Mediterranean geography and established their religious rule (ideological realpolitik power in the society) in the Dark Period which is considered to start particularly after the Phenomenon of $12^{\text {th }}$ century B.C. (Sea Tribes), specific to the masculine celestial god which is the chief figure of their pantheons. We suggest reading this period as the Narrative Period. We read this refraction in Aegean Cultures in the form of Zeus religion and rule of the third generation gods (Olympus habitants). This change cannot be considered as a simple historical event analysis. This very significant period where the paradigm is refracted and reconstructed in another form is named as the Dark Period. Dark Period is a very productive stage and revealed the Ancient Greek Culture. The most significant element of this early production is discursive production. We call this production mythology. On the basis of this production we can understand and analyze the cultural production called Ancient Greece. The mother goddess persona in the Ancient Greek religion is not a single divine figure. Different goddesses have roles different from the ancient mother goddess under Zeus' final rule. Artemis, Demeter, Athena, Hestia, Hera, Aphrodite have been the reflections of the goddess in the Continent in this context. Specific to nature and agriculture, Artemis and Demeter (wheat agriculture) prevail. ${ }^{39}$

The society is definitely and finally an agricultural society in the early periods of the Ancient Greek culture. Calydon, the most significant city (settlement, kingdom) of Aitolia Region is an agricultural society, too. Calydon Wild Boar Hunting mythos, one of the most significant mythos of the Narrative Period is the discourse of an agricultural society. It is the transformation discourse of an agricultural society. It is the discourse of network of relations among this transformation and an agricultural society and a kingdom. Here the economic-political indicators of religious and ideological transformation are available. What is in question here is social class, inter-class hierarchy, production and production models $\mathrm{s}^{40}$, commodity, production and preservation of added value, class conflict and indicates the transition tensions in the construction of orderly and conservative structure, continuity and preservation parergon. However Classical Paradigm used this transformation in the construction of divine sin and punishment under the appearance of an ancient mythos of the Heroic Age.

\footnotetext{
${ }^{39}$ Okan, age, 109-168.

${ }^{40}$ G.E.M. de Ste. Croix, Antik Yunan Dünyasında Sınıf Mücadelesi, Çev. Çağdaş Sümer, Yordam Kitap, İstanbul 2016, s. $27,30,41,46,53-54,57,61,67,74,75-79$.
} 


\section{Bibliography}

See for Works; Der Kleine Pauly 1964, Archaeologischer Anzeiger 1992 ve Archaeologische Bibliographie 1993.

\section{Classics:}

Apollod.

Apollodoros, The Library-Bibliotheke (Çev. J.G. Frazer),

Londra, 1921.

Diod.

Diodorus Siculus (Çev. C.H. Oldfather), Londra, 1933.

Hom. Il.

Homeros, İlyada (Çev. A. Erhat - A. Kadir), İstanbul, 1984.

Kall. h.

Kallimakhos, Hymni (Çev. A.W. Mair),

Ov. met.

Ovidius, Metamorphoses (Çev. F.J. Miller), Londra, 1916-1929.

Paus.

Pausanias, Description of Greece-Periegesis tes Hellados (Çev.

W.H.S. Jones), Londra, 1926-1933.

\section{Modern Works:}

BAHTIN, Mihail Mihayloviç, Söylem Türleri ve Başka Yazılar, Çev: Okan N. Çiftçi, Metis Yayınları, İstanbul 2016.

BARNARD, Alan, Simgesel Düşüncenin Doğuşu, Çev: Mehmet Doğan, Boğaziçi Üniversitesi Yayınları, İstanbul 2016.

BARFOED, Signe, "The Cults of Kalydon, Reassessing the Miniaturised Votive Objects", Proocedings of the Danish Institute at Athens, Vol. VIII, Edt. K. Winther-Jacobsen, R. Frederiksen, S. Handberg, Atina, 2017, s.131-148.

BARFOED, Signe, "Rediscovering Artemis Laphria at Kalydon", Proocedings of the Danish Institute at Athens, Vol. IX, Edt. K. Winther-Jacobsen, N. von Eggers Marieggard, Atina, 2019, s.189-196.

BELLAH, Robert, Neelly, İnsan Evriminde Din, Eski Taş Çă̆ından Eksen Çağına Çev: Mete Tunçay, İstanbul Bilgi Üniversitesi Yayınları, İstanbul 2017.

BOARDMAN, John, “Atalante”, LIMC II, 1984, s. 940-950.

BOARDMAN, John, Siyah Figürlü Atina Vazoları, Çev: Gürkan Ergin, Homer, İstanbul 2003.

BOARDMAN, John, Yunan Sanatı, Çev: Yasemin İlseven, Homer, İstanbul 2005.

BOARDMAN, John, Yunan Heykeli. Geç Klasik Dönem, Çev. Müjde Peker, Homer, İstanbul 2014.

BOURDIEU, Pierre, Akademik Aklın Eleştirisi, Pascalca Düşünme Çabaları, Çev: P.Burcu Yalım, Metis Yayınları, İstanbul 2016.

BURKERT, Walter, Greek Religion, Harvard University Press, Massachusetts 2003. 
CARPENTER, Thomas, H., Antik Yunan'da Sanat ve Mitoloji, Çev: Bensen B.M. Ünlüoğlu, Homer Kitabevi, İstanbul 2002.

CROIX, G.E.M. de Ste., Antik Yunan Dünyasında Sinıf Mücadelesi, Çev: Çağdaş Sümer, Yordam Kitap, İstanbul 2016.

DUGAS, Charles - Berchmans, Jules - Clemmensen, Mogens, Le Sanctuaire d'Aléa a Tégée au IVe siécle, Paris 1924.

ELIADE, Mircea, Mitler, Rüyalar ve Gizemler, Çev: Cem Soydemir, DoğuBat1, İstanbul 2017.

ELLINGER, Pierre, “Artemis”, Antik Dünya ve Geleneksel Toplumlarda Dinler ve Mitolojiler Sözlüğ̈̈, Ed. Yves Bonnefoy, Dost Kitabevi, Ankara 200, s.65-69.

ERHAT, Azra, Mitoloji Sözlüğ̈̈, Remzi Kitabevi, İstanbul 1996.

FITTSCHEN, K., Meleager Sarkophag, Frankfurt am Main. 1975.

FREUD, Sigmund, Dinin Kökenleri, Çev: Ayşen Tekşen, Pavel Yayınevi, İstanbul 2012.

GRAVES, Robert, Yunan Mitleri C.1, Çev: Uğur Akpur, Kolektif, İstanbul 2020.

GRIMAL, Pierre, Dictionnaire de la Mythologie grecque et romaine, Paris 1969.

HAMILTON, Edith, Mitologya, Çev: Ülkü Tamer, Yapı Kredi Yayınları, İstanbul 2018.

İNDİRKAŞ, Zühre, Antik Yunan'da Mitosun Serüveni, Tekne Yayınları, İstanbul 2017.

JUNG, Carl, Gustav, Dört Arketip, Çev: Zehra Aksu Yılmazer, Metis Yayınları, İstanbul 2015.

KERENYI, Karl, Yunan Mitolojisi; Tanrılar, İnsanlar ve Kahramanlar, Çev: Oğuz Özügül, Say Yayınları, İstanbul 2019.

KOCH, G., Die mythologischen Sarkophage 6; Meleager, Berlin 1975.

KOCH, G., Sarkophage der römischen Kaiserzait, Darmstadt 1993.

KORTANOĞLU, R., Eser, Atalante; İkonografik Bir Inceleme, (İstanbul Üniversitesi, Sosyal Bilimler Enstitüsü, Yayımlanmamış Yüksek Lisans Tezi), İstanbul 1999.

KORTANOĞLU, R., Eser, "Kalydon Yaban Domuzu Avının Kadın Kahramanı Atalante Üzerine İkonografik Veriler Işığında Bir İnceleme", Anadolu Araştırmaları/Jahrbuch für Kleinasiatische Forschung XVI, 2002, s.425-447.

KORTANOĞLU, R., Eser, "Une Femme Sportive Dans Les Mythes Grecs Antiques", Colloquium Anatolicum X, 2011, s.167-179.

KORTANOĞLU, R., Eser, Varlık ve Tapınak; Eski Yunan Tapınağının Kavramsal İnşası Üzerine Arkitektonik Bir Deneme, Bilgin Kültür Sanat, Ankara 2018a.

KORTANOĞLU, R., Eser, "Yas (Mourning)", A. Vedat Çelgin'in 68. Doğumgünü Onuruna Makaleler. İstanbul 2018b, s.529-534.

KORTANOĞLU, R, Eser, "Logocentric Structures, Platon and Dual Worshipping Phenomenon”, VI. Yıldı Teknik Üniversitesi Sosyal Bilimler Kongresi 12-13.12.2019, Tam Metin Bildiri Kitabl. İstanbul 2019, s.281-290. 
KORTANOĞLU, R. Eser - Müge Savrum Kortanoğlu, "Kita Yunanistan Mimarisinde Birden Fazla Girişi ve Mekanı Olan Anıtsal Yapılar: Tarihöncesi ve Tarihsel Uzamlar, Kütleler ve Çevirileri”, Cedrus VIII, 2020, s.117-134.

LACAN, Jacques, Baba-nın Adları, Çev: Murat Erşen, Monokl, İstanbul 2014.

LACAN, Jacques, Psikanalizin Dört Temel Kavramı, Çev: Nilüfer Erdem, İstanbul 2017.

LEVI-STRAUSS, Claude, Yaban Düşünce, Çev: T. Özgüç, Yapı Kredi Yayınları, İstanbul 2000.

LEVI-STRAUSS, Claude, Yapısal Antropoloji, Çev: Adnan Kahiloğulları, İmge Yayınları, Ankara 2012.

LEVI-STRAUSS, Claude, Uzaktan Yakından, Çev: Haldun Bayrı, Metis Yayınları, İstanbul 2018.

MARCH, Jenny, Klasik Mitler, Çev: Semih Lim, İletişim, İstanbul 2018.

OKAN, Cansın, Mitoslar ve Tasvirler Işı̆̆ında Antik Ege Coğrafyasında Dişi Tanrısal Figürler: Kök, Karışım ve Değişim. (Anadolu Üniversitesi, Sosyal Bilimler Enstitüsü, Yayımlanmamış Yüksek Lisans Tezi), Eskişehir 2019.

ROSENBERG, Donna, Dünya Mitolojisi, Büyük Destan ve Söylenler Antolojisi, Çev: Koray Akten - Erdal Cengiz, İmge Yayınları, Ankara 1998.

SAGLIO, E., "Atalante”, Daremberg-Saglio I, 1877, s.510-511.

SCHNAPP, A., “Av. Eski Yunan'da Av Kahramanları ve Mitleri”, Antik Dünya ve Geleneksel Toplumlarda Dinler ve Mitolojiler Sözlüğ̈̈, Ed. Yves Bonnefoy, Dost Kitabevi, Ankara 2000, s.90-92.

SIMON, Erika, Meleager und Atalante. Abegg-Stiftung, Bern 1970.

STEWART, A.F., Skopas of Paros, New Jersey 1977.

STEWART, A.F., Skopas in Malibu. California 1982.

STEWART, A.F., Greek Sculpture. Yale University Press, New Haven 1990.

WOODFORD, Susan, “Meleagros”, LIMC VI, 1992, s.414-435. 